\title{
British Imperialism and the Political Economy of Malayan Independence
}

\author{
Alex Sutton \\ Published in Journal of Imperial and Commonwealth History 2016
}

Word Count: 9714

\begin{abstract}
The paper focuses on Britain's relationship with Malaya shortly before and after its independence from the British Empire. The paper looks at the negotiations concerning the financial settlement prior to independence. Britain sought to keep Malaya within the Sterling Area at all costs, even after de jure convertibility had been achieved, due to its high dollar earning capacity, which remained important due to persistent trade deficits with the US since the end of the Second World War. The paper argues that this settlement, while seemingly very generous for an independent Malaya, was still very much intended to maintain Britain's role within the global economy, to ensure Sterling's status as an international currency, and to support conditions for British economic growth.
\end{abstract}

\section{Introduction}

This paper charts Britain's negotiations with Malaya over its eventual independence, and Malaya's relationship with Britain immediately after independence. The discussions were split in two. The first, a set of constitutional talks held in January and February 1956, laid down the basic form that Malayan independence would take. These talks were followed by the creation of a special commission, which toured Malaya until late-1956, publishing a report, the Reid Report, on independence in March 1957. ${ }^{1}$ Prior to the publication of this report, however, from December 1956 to January 1957, were more substantial discussions on the nature of mutual defense and the specifics of financial arrangement post-independence. ${ }^{2}$ This paper focuses on the latter of these and seeks to understand these discussions in terms of the goals of British state managers.

The paper begins with a brief overview of the lead-up to the Constitutional Talks in early1956, focusing principally on a disagreement between Britain and Malaya over British imports of synthetic rubber from the dollar area. The second section focuses specifically on the Constitutional Talks, which were dominated by the issue of dollar spending. The paper's third section deals with the late-1956 Financial Discussions and the issue of development aid for the Malayan economy. The final section covers the immediate post-independence period. Throughout all of these sections, the enduring theme is Malaya's continuing value as a high net dollar earner to the Sterling Area's dollar pool, and its persistent importance to the maintenance 
of British international economic policy. While Malaya begins to act more independently, and indeed receives formal independence, from Britain, Malaya simply acts more independently within the relationship that already exists, using the nature of the relationship to its own advantage and not actually challenging its basic structure.

The understanding by Malaya's own state managers of its value to the Sterling Area, and hence to British economic and monetary policy, reveals the nuance of this imperial relationship. The institutional arrangement provided by the Sterling Area permitted Britain to centrally pool convertible currency reserves and for Sterling to be used as a reserve and trading currency by a number of states. It is this arrangement that simultaneously permitted the domination by Britain of Malaya to its own ends but also for Malaya to recognise its own value and to leverage benefits from Britain, resulting in development, economic growth and increased autonomy from Britain. The relationship between Britain and Malaya, both before and after independence, offers an insight into the nature of imperialism. Rather than seeing this relationship as simple one-way domination, as classical and dependency theories of imperialism have argued, this episode reveals the collaboration between and shared goals of both British and Malayan state managers. ${ }^{3}$ This is not to suggest that imperialism is a meeting of equals, or a conspiracy between state managers. On the contrary, this is a fundamentally unequal relationship that developed throughout the $19^{\text {th }}$ and $20^{\text {th }}$ Centuries according to the needs of the British state and economy. As such, it is imperative to understand this relationship as anchored in the context of both British state managerial goals and the demands of the global economy.

\section{British-Malayan Relations}

The subject of Malayan independence has received some noteworthy scholarly attention. From broader accounts of British imperial relations, including those of Krozewski and Hinds, whose accounts of colonial independence, such as Malaya's, rest on a curious mix of continuity and discontinuity based upon the formal end of empire and the existence of sympathetic elites in post-colonial states. ${ }^{4}$ Their accounts, however, focus on the broader trend of decolonization rather than specific cases. More specific scholarly attention derives from the work of Schenk, Strange, White and Harper. ${ }^{5}$ Their more focused analyses offer stronger evidence for continuity, particularly in the case of White, who offers substantial archival evidence to support claims of continuity. ${ }^{6}$

However, lacking in their accounts is an attempt to situate Malayan independence in 
terms of the broader political economic environment Britain faced in the 1950s. White focuses more on Malayan-Asian trade patterns, while Harper focuses on the making of the post-colonial Malayan state - a similar focus as Amin and Stockwell, albeit in less radical terms. ${ }^{7}$ Indeed, Harper notes that his goal was to understand decolonization "as seen from Malaya and not from London". ${ }^{8}$ The goal of this paper is the exact opposite to Harper's work and seeks to understand how British state managers sought to retain Malaya within the Sterling Area. Also lacking in their accounts is a critical analysis of why it remains in Malaya's interests to remain a part of the Sterling Area and to link this with Britain's political and economic situation at the time.

Both Strange and Schenk provide accounts of the establishment of the Malayan Central Bank in 1959, which was discussed at the negotiations over independence. ${ }^{9}$ Where Strange argues that Britain was resistant to its establishment due to a desire to have Malaya still economically dependent on Britain, Schenk argues that Malaya was not entirely enthusiastic about the prospect of full monetary independence from the UK. Schenk argues this was due to both the potential political and economic difficulties posed by uniting Malaya with Singapore, and the desire to represent institutional continuity after independence to ensure Malaya remained an enticing location for foreign investment. While both accounts are very interesting, Strange's account provides no primary sources to support her conclusions, and Schenk's account fails to provide a critical explanation behind the logic for Malaya's reticence to enthusiastically pursue monetary independence. For example, there is no reflection upon the fact that both Malaya and Britain see continuity within the Sterling Area as a means for economic stability - it is merely presented as the reason for Malayan reluctance to pursue monetary independence ${ }^{10}$ Furthermore, this paper, while certainly concerned with economic and monetary issues, does not intend to focus at great depth on the establishment of the Malayan Central Bank, its origins in the International Bank mission to Malaya in 1954, or the specific nature of the negotiations in its setup.

The goal of this paper is not to dismiss the literature but rather to emphasize aspects of it through an analysis of the negotiations over the political economic consequences of independence. All agree that Malaya remained important to the Sterling Area into the 1950 due to its dollar-earning capacity. ${ }^{11}$ However, this point tends to get lost in a desire to find instances of discontinuity. Either these approaches tend to focus on the broader issue of decolonization and hence miss the specifics of each relationship ${ }^{12}$, or focus on the specifics of British-Malayan relations but do not interrogate the nature of that relationship. ${ }^{13}$ As such, this paper does not 
reject the literature but seeks to fill a gap in understanding the relationship between Britain and Malaya. To do this, the paper will analyze the moment of the apparent shift from 'formal' to 'informal' empire, looking at the negotiations over independence, to understand how, why and on what terms Britain wanted Malaya to remain in its imperial economic domain, the Sterling Area. Finally, it is also worth noting that, while mentioned in a number of works, close analysis of the negotiations over independence themselves is also lacking and so empirical questions can be raised: what were the key issues and problems in these negotiations? ${ }^{14}$ How were they resolved? And how do they tie into the broader political economic situation at the time?

\section{Synthetic Rubber}

Initially, the Constitutional Talks in London in early 1956 looked set to be dominated by the issue of imports of synthetic rubber to Britain. The Colonial Office had been approached by the Federation's Minister for Economic Affairs, who wanted to know why Britain was using the dollar pool to purchase synthetic rubber rather than simply purchasing Malayan natural rubber. ${ }^{15}$ There was some anger in Malaya that, for all Britain's declarations of support concerning development, Britain was unwilling to support the Malayan rubber industry with its custom. The British government had approved an import programme for 70,000 tons of synthetic rubber in 1956 from the US, which corresponded to a drop in orders for Malayan natural rubber by 70,000 tons for that year.

The Treasury responded to the request by pointing out that the UK abided by rules common to the entire Sterling Area - dollar expenditure was acceptable as long as it was for essential purchases. Synthetic rubber imports were considered essential purchases as the efficiency and competitiveness of the UK rubber manufacturing industry relied on them. The Treasury maintained that the import programme in 1956 was not excessive and therefore was a justifiable use of dollars. The Treasury also refused to review the programme. ${ }^{16}$

The Colonial Office sent a letter to Donald MacGillivray, the High Commissioner of the Federation of Malaya, a few days after the initial Treasury response to reiterate the reasons for the synthetic rubber imports, and the stubbornness about maintaining them. In the letter, Lennox-Boyd, the Colonial Secretary, emphasised that this policy was entirely consonant with Sterling Area rules but aimed ultimately at the convertibility of Sterling. This aim could not be accomplished until the Sterling Area's balance of payments had been strengthened and the only means of achieving that was to improve the efficiency, productivity and competitiveness of the 
British economy. The argument then proposed by the Colonial Office and the Treasury was that the import of synthetic rubber was justifiable in terms of Britain and the Sterling Area's general economic policy. ${ }^{17}$

Average natural rubber prices in 1955 had reached a post-Korean war high of around $34 \mathrm{p} / \mathrm{lb}$., which had stimulated the competitiveness of synthetic rubber production. ${ }^{18}$ The use of synthetic rubber was also preferred for a great deal of rubber manufacturing end uses and Lennox-Boyd argued that the import of synthetic rubber in this instance would greatly reduce the need to import any more in the future. Furthermore, since European rubber manufacturing industries had not had access to Britain's rubber markets, their industries were considerably more efficient and competitive than Britain's own. ${ }^{19}$

While Lennox-Boyd was very eager to emphasise that Malaya's rubber and tin industries were essential to the dollar earnings of the Sterling Area, their protection could not come at the price of British and the Sterling Area's development as a whole. Indeed, the Colonial Office made clear that import controls on essential dollar imports were contrary to the Sterling Area's economic policy and also asserted that GATT obligations required that Britain should not employ quantitative import restrictions for protective purposes, despite using exactly the opposite argument in the mid-1940s to justify quantitative import restrictions. ${ }^{20}$ The Colonial Office's final point was to say that imports of Malayan rubber into Britain were of such a small amount that swapping synthetic imports for Malayan imports would have little effect indeed. Natural rubber was principally consumed in the US market, where natural and synthetic rubber was in free competition. $^{21}$

The arguments put forward by both the Colonial Office and the Treasury to the Federation, and subsequently reiterated by the High Commissioner in Malaya, settled the matter on the specific issue of synthetic rubber imports. However, the concern over the issue was merely a manifestation of a more fundamental problem running throughout the Britain-Malaya relationship: the use of dollars earned by Malaya. This became the theme of the Financial Working Group in the Constitutional Talks held in London between January and February 1956.

\section{Dollar Imports}

In a Bank memo, a copy of the brief for the Malayan Minister for Economic Affairs was discussed by John Fisher, the Deputy Chief Cashier, Sir George Bolton, Executive Director at the Bank, and Lucius Thompson-McCausland, Adviser to the Bank's Governor, in detail. Financial issues and 
exchange policy were to be discussed in relation to Malaya's imports from the dollar area and its dollar spending, as well as its future financial ties with Britain and the Sterling Area. The Minister's brief contained three demands, and one offer:

- Full membership of the Sterling Area, so that Malaya will be consulted on matters of common policy and will be invited to attend Finance Ministers' meetings;

- Britain was to accept that Malaya's capital requirements were to be met in the London market, to the tune of $f 20 m$ over the next five years;

- Malaya was to have freedom to import from dollar sources, and to have free access to its own dollar surplus in order to develop its economy to expand trade with neighbouring countries;

- In return for the above, Malaya would pledge full collaboration and cooperation on all matters affecting Sterling and convertibility. ${ }^{22}$

The first demand was not discussed because it was wholly acceptable. For the second demand, the Treasury reported it could not assure the Malayan delegation that this was possible, though there were precedents for that to occur. ${ }^{23}$ The third demand was considered the most important and an immediate issue for the Talks, and saw the Bank provide an insight into divisions on Sterling Area policy within the state management.

"If Malayan ministers press for freedom on dollar imports and if this is largely conceded (whether for political reasons or otherwise) it will make an irreparable breach in the wall of dollar restrictions around the Colonies which the Treasury seek to maintain - and which we are anxious to lower". ${ }^{24}$

Once again, the Bank's major concern was that it would set a dangerous precedent for the Sterling Area. If this were permitted, it would be difficult to deny similar concessions to other countries (e.g. the colonies of the former British West Africa) and therefore, according to the memo, the Colonial Office too would have to abandon its current efforts to keep all Colonies on the same exchange policy. ${ }^{25}$ The Bank then was much more committed to the Collective Approach than the Colonial Office or the Treasury, who were still committed to the maintenance of exchange controls around the Sterling Area. However, by this point, the Collective Approach had been widely accepted by British state managers and the Sterling Area and, therefore, the Bank, as Burnham argues, was much more eager to act swiftly to achieve Convertibility. ${ }^{26}$ 
One possibility of getting around Malaya's demand for free dollar imports was to use Hong Kong as a 'back door' through which Malaya could buy all the dollar goods it needed. Hong Kong's special status was brought up by the Malayan delegation, since Hong Kong had much greater dollar freedom than any country in the Sterling Area. ${ }^{27}$ However, this was because Hong Kong was an entrepot area for China, Korea, Macao, and Taiwan and sold large quantities of goods to these territories and in return received large quantities of dollars, which Hong Kong was permitted to use freely. ${ }^{28}$ Hong Kong's dollar earnings actually provided a net contribution to the Sterling Area, while Sterling accounts in the colony were restricted and the Hong Kong government enforced this by strictly limiting the sale and purchase of Sterling. Furthermore, the Malayan dollar was linked to Sterling through statute but the Hong Kong dollar was a de facto link, with no strict basis in law. Unlike Malaya, Hong Kong was not legally obliged to back its currency with Sterling or to issue against Sterling at a fixed rate. As such, Hong Kong was seen as a very special case. ${ }^{29}$
"A free market like Hong Kong's is contrary to the fundamental principles of the Sterling Area and to HMG's obligations to the IMF. The arrangements in Hong Kong are in effect a compromise between its two roles as an outlet for China and neighbouring countries and as a Sterling Area territory; they can only be justified because of the exceptional circumstances, which are of over-riding importance to the economic existence of the territory concerned. ${ }^{\prime \prime 30}$

It was then put to the Malayan delegation that there was no justifiable comparison between the Malayan and Hong Kong economies, which they were satisfied with. ${ }^{31}$ John Fisher, Deputy Chief Cashier at the Bank, made one further point that the most basic and convincing argument against a Malayan free market was Malayan development. ${ }^{32}$ Malaya required stability in order to develop and, as such, fluctuating exchange rates would run contrary to this since they would require a barrier between Malaya and the Sterling Area instead of the current statutory arrangement. ${ }^{33}$

Given the failure of the comparison between Malaya and Hong Kong, a member of the Malayan delegation approached the Chief General Manager of Chartered Bank, Howard Morford, to tell him that the Malayan delegation was now considering setting up Singapore as a free market in US dollars, as Hong Kong. Morford asked PL Hogg at the Bank to see if there were good arguments that could be mustered by either the Bank or the Treasury to dissuade the Malayans of this course of action. ${ }^{34}$ 
The purpose behind this determination to achieve free use of dollars was, of course, for Malaya to expand its primary and secondary industries and a free market was seen by the Malayan delegation as attracting overseas capital to invest in the Malayan economy. However, the Bank was adamant that there was no guarantee of this and that a free market could actually encourage instability and uncertainty. ${ }^{35}$ Further, if it were just Singapore to become a free market then exactly the same arguments applied as if Malaya as a whole wished to have a free market: exchange barriers would be required, it would strain the link between currencies, and it was entirely dissonant with Malaya's professed intention of staying in the Sterling Area and committing to the obligations inherent to that. ${ }^{36}$

By the end of the Constitutional Talks in mid-February 1956, a provisional agreement had been reached about the lead-up to the Federation's independence. The Talks had led to an agreement that an elected Malayan Finance Minister would take over all responsibility for internal and external finance from the (London-appointed) Financial Secretary with immediate effect. Malaya would remain in the Sterling Area after independence, which was scheduled for August 1957, and Malaya would send delegates to all future meetings of Finance Ministers. Control over the Federation's dollar spending would move from Whitehall to the Federation government, who would then be tasked with applying Sterling Area policy to Malaya as a whole. ${ }^{37}$ Assurances were given to Malaya that "sympathetic consideration" would be given to Federation borrowing in London for development purposes. ${ }^{38}$ Furthermore, Britain pledged to give fair treatment to overseas capital investment in the Federation and agreed to aid in meeting the costs of the Emergency after independence. ${ }^{39}$ The final report on the Constitutional Conference characterised the agreement made between Malayan and British delegations on the Sterling Area

"We had a full and frank discussion of the Federation's position in the Sterling Area. The Malayan Delegation indicated that it was the view of their Government that membership of the Sterling Area was to the common advantage of the Federation and the other members and that it was their intention to remain in it after attaining full self-government. There was general recognition by the United Kingdom representatives of the importance of the Federation's contribution to the strength of the Sterling Area through the direct earnings of dollars from rubber and tin." ${ }^{40}$

A letter from Herbert Brittain, second secretary at the Treasury, to Thomas Lloyd, Permanent Under-Secretary of State at the Colonial Office, a week after the Constitutional Talks 
emphasised how important the colonies were to the British economy and how crucial it was still to maintain strict limits on dollar expenditure.

"We cannot regard Colonial economies as 'entirely external' to that of the United Kingdom. Such description would, indeed, have little meaning. For years now it has been necessary to emphasise the inter-connectedness of internal and external problems, and... vigorous internal measures are necessary to relieve the balance of payments... The fact remains, however, that external spending, even in the sterling area, has a more direct and a larger effect upon our reserves and the status of sterling than expenditure at home, and has for that reason to be examined with special care." ${ }^{\prime 11}$

Colonial Sterling Balances had recently risen and this was helpful to Sterling's position and also therefore to Britain..$^{42}$ However, Brittain emphasized clearly to Lloyd that the Colonies could not be permitted to run down their Sterling Balances by spending freely as this would still place too great a strain on the reserves, they would dwindle to nothing in the process, and the Colonies would suffer as much from that as Britain. ${ }^{43}$ Britain's dollar reserves in February 1956 were still very low at $£ 77 m$, with gold reserves at their lowest level since June 1953 at $£ 703 \mathrm{~m} .{ }^{44}$

Immediately following the Constitutional Talks, a new Minister of Finance, as per the agreement with Britain, was appointed in the Federation. Colonel Henry Lee was a Chinese Malay who had been bestowed the honorary rank of Colonel by Chiang Kai-Shek. His political activities were decidedly anti-communist and he was a very wealthy man, holding considerable business interests in both the Federation in Singapore in rubber estates and tin mines. ${ }^{45}$ Lee, like British officials, did not want to see Singapore become a free dollar market. Lee became the key figure in all of Britain's financial discussions with Malaya until 1959 and during this time the same issues dominate Britain's relationship with Malaya, even after independence. ${ }^{46}$

The Constitutional Talks had cemented Malaya's continued position as a central element of Sterling Area policy, which senior British state managers at the Bank and Colonial Office had been eager to achieve. The subsequent Financial Discussions in late-1956, however, would bring into question the specifics of the terms set up by the Constitutional Talks.

\section{Financial Discussions}

In early June 1956, Malayan ministers met with representatives from the Eastern Banks to discuss 
the setting up of an investment corporation to stimulate industrial development in the Federation to the tune of M\$10m. While the Banks wanted a majority government share in the corporation, the Federation government sought to have the corporation based on majority private investment. ${ }^{47}$ The Federation was also using the terms of the creation of a Central Bank as a bargaining chip for the setting up of the investment corporation and, in a letter to the Bank of England, the Mercantile Bank felt that the setting up of the corporation revealed a desire to cut ties with Singapore. ${ }^{48}$

While the Colonial Office admitted they were not aware of the creation of the Industrial Development Corporation, they informed the Bank that this was usual for colonies heading towards independence and there were precedents for it. However, they acknowledged that, ordinarily, the Colonial Development and Food Corporation (CDFC) would provide funds for the corporation but the Malayan government had not approached the CDFC for funds ${ }^{49}$ Colonel Lee also contacted the British government at this point to ask for financial aid for Malayan development; however, the Colonial Office was reticent to approve any funds unless the details of a specific development plan were provided but these had not yet been drawn up by the Federation. ${ }^{50}$

Certainly, the Federation was very eager to gain access to large amounts of ready cash to spend on development in the run up to independence..$^{51}$ Indeed, by the end of June, Donald MacGillivray telegrammed Alan Lennox-Boyd to inform him that the Federation had asked him about lifting the rubber embargo against China. ${ }^{52}$ The High Commissioner had informed Colonel Lee that the British government would require an end-use certificate due to security concerns about its application; however, this would probably be meaningless and therefore he suggested using a quantitative restriction instead and proposed an initial limit of 2000 tons of rubber. ${ }^{53}$ The embargo on rubber exports to China was ultimately relaxed. It was too difficult to get end-use agreements from the Chinese government but Malayan exports assured Sir Robert Black that their rubber exports were used only for civilian purposes. These shipments constituted the first rubber exports to China from Malaya since $1951 .{ }^{54}$

By August, however, Britain was forced to deal with the repercussions of the nationalization of the Suez Canal, an action described in the Bank as imperilling "the survival of the UK and the Commonwealth, and represents a very great danger to Sterling". ${ }^{55} \mathrm{~A}$ letter to the Governor of the Bank highlighted that the use of economic warfare against Egypt would be detrimental to Britain, especially to the reserves. ${ }^{56}$ This was not catastrophic at the time, as the 
reserves had reached a comparative highpoint with dollar reserves at $1137 \mathrm{~m}$ and with gold reserves at $£ 722 \mathrm{~m} .{ }^{57}$ However, the Suez crisis, due to both economic warfare and the effect on Sterling, diminished the reserves significantly. By the end of August dollar reserves had fallen to $£ 88 \mathrm{~m}$, and by the end of November had fallen again to $£ 47 \mathrm{~m}$, with gold reserves at $£ 655 \mathrm{~m} .{ }^{58}$

By even mid-November, George Bolton, in discussion with Leslie Rowan, agreed that Britain could not continue to take losses as they had been and still hope to maintain the rate of Sterling, which was essential since if that rate could not be maintained, "there [was] a grave risk of the Sterling Area coming to an end". ${ }^{59}$ They agreed that an appeal to the US to help maintain parity was necessary since "it is a major interest of the US to maintain Sterling and to prevent the collapse of the Sterling Area"; however, this was not forthcoming and the reserve situation only abated with Britain's unconditional withdrawal from the Suez Canal Zone, with dollar reserves rallying up to $f 166 \mathrm{~m}$ by the end of the year. ${ }^{60}$

Against this backdrop, Financial Talks between Britain and the Federation were being prepared, starting on December $17^{\text {th }} 1956$. The Federation had begun to worry about revenues after independence, as the IBRD's report on Malaya's economic development suggested that rubber prices would fall between 1957 and 1960. ${ }^{61}$ The Federation then sought further financial assistance from the British government but the Colonial Office was reticent to accede to, what they termed, Malaya's "exorbitant demands", considering them extremely unreasonable. ${ }^{62}$

In communication with the Colonial Secretary, the Commissioner-General of South East Asia, Sir Robert Scott, reiterated the High Commissioner's plea that the Colonial Office accept Malaya's request for generous aid. He emphasized that the financial situation in Britain would certainly be better suited to the economic arguments for doing so but these arguments supported broader political ones. ${ }^{63}$ While there were substantial British investments in Malaya, running to hundreds of millions of pounds, plus the invisible earnings accruing from shipping, banking and insurance, this was not the best argument for being generous with Malayan development aid. ${ }^{64}$

"The main economic argument for financial aid is, quite simply, dollars. On the prosperity of Malaya and on the stability of its economy depends one of the biggest single sources of American dollars at the disposal of the Sterling bloc, if not indeed the biggest individual source. Malaya earns some hundreds of millions of dollars a year, a quarter or more of the total dollars accruing to the 
whole sterling area. Surely the greater the strain on sterling, the greater the need to conserve such a vital source of dollars. If that can be done by sterling expenditure, it is cheap at almost any price. ${ }^{165}$

Essential to Malaya's source of dollars was the rubber industry and Abdul Rahman contacted the Colonial Secretary the day after Sir Robert Scott's letter to assure him that rubber replantation was the highest priority in the Federation's development plan. ${ }^{66}$

The Colonial Office were initially very concerned that the financial discussions would be focused on Malaya's relationship with the Sterling Area and prepared another document detailing the value Malaya gained from remaining in the Sterling Area. ${ }^{67}$ However, in conversation with the Bank, the Colonial Office was informed that Malaya's position in the Sterling Area were unlikely to come up again since the issue had been extensively covered in the Constitutional Talks at the beginning of 1956; instead, the discussions were most likely to focus on finance for Malaya's defence and development programmes. ${ }^{68}$

Given Britain's weakened state following the Suez crisis, the Financial Talks were difficult. The Malayan delegation demanded that Britain meet half the cost of the Emergency, ${ }^{69}$ and help to meet the costs of Malaya's development plan. The Federation then asked for a f10om grant to bridge the gap between Malaya's capacity and requirements. ${ }^{70}$ The British delegation responded starkly by saying that the British government did not and could not give direct financial aid to independent members of the Commonwealth for development since it was considered "a normal economic activity in which any independent Government must stands on its own feet" and there was a stated suspicion among the British delegation that, if the costs were spread out, the Federation could meet them. ${ }^{71}$ The Malayan delegation, which included Abdul Rahman and Colonel Lee, were extremely disappointed with this response from the British.

However, as had been agreed in the Constitutional Talks in early 1956, Britain would provide financial aid to meet the costs of the Malayan Emergency. This was not only seen as a contribution to the Emergency but also to the Federation's development plan as it freed up significant resources, with the development of Malaya "recognized to be in itself an important contribution to the fight against communism". ${ }^{72}$ Britain agreed to provide an annual grant of $£ 3 m$ each year for the following three years and, at the end of those three years, the British government agreed to review the Federation's financial position and then decide on whether to activate a fund of $111 \mathrm{~m}$ for further assistance, to be spread over the next two years. ${ }^{73}$ In addition, 
Britain offered to use already-promised funds of $£ 6.5 \mathrm{~m}$ to the Federation to further expand its armed forces, as well as supplying equipment up to the value of $£ 5.5 \mathrm{~m} .{ }^{74}$ These amounts would be in conjunction with a grant to the Federation for development from the unspent balance of the Federation's Colonial Development and Welfare allocations at the date of independence, which was around $£ 4.5 \mathrm{~m} .{ }^{75} \mathrm{In}$ all, this amounted to grants of nearly $£ 37 \mathrm{~m}$ until 1961 , about which both Abdul Rahman and Colonel Lee were very pleased. ${ }^{76}$

With Malayan capital expenditure very high at around M\$26om, Malaya needed as much money as it could get. However, despite a recommendation in the IBRD report that Malaya could seek local development loans worth around M\$1om per year through the Malayan Post Office Savings Bank (POSB), the Bank of England were extremely reticent to support this notion. ${ }^{77}$ There would be a great risk of capital loss to the POSB, since there was no limit on the amount of government stock the POSB could purchase, the POSB's portfolio would be extremely limited, and "in an economy as dependent as the Federation on the vicissitudes of the world markets for tin and natural rubber, the interests of depositors must surely be carefully watched and not sacrificed for development expedience ${ }^{\prime \prime}{ }^{78}$ So while British officials were eager for Malaya to have as much cash as possible to spend on development, this was not the key priority - Malayan development was instrumental in terms of dollar earnings, but also and importantly, the stability of the economy and the Malayan political establishment.

Despite the relative distance now from Suez, the effects were still being felt in the British economy, including the prolonging of oil supply difficulties; however, both Leslie Rowan and Denis Rickett were sanguine, in a letter to Cameron Cobbold, about the position of Sterling due to the resolution of domestic political instability through Eden's resignation at the beginning of 1957, and the boost likely to be given to Sterling through the seasonal effect on Sterling Area commodities. $^{79}$

Bound up tightly with the issue of Malayan independence, and the value of Malaya's Sterling Area membership, was the issue of economic development. In order for Malaya to remain a persistent and consistent dollar earner, the British state had to, in some form, invest in the Malayan economy. This was a point acknowledged and agreed by both Malayan and British state officials, and most clearly articulated by Sir Robert Scott by placing Malaya's continued importance in the context of Britain's continued economic vulnerability. 
With independence granted to Malaya on $31^{\text {st }}$ August 1957, Malaya assumed a full membership of the Sterling Area and the Commonwealth. ${ }^{80}$ An interview with Lord Kilmuir, the Lord Chancellor, was arranged for the BBC to discuss Malaya's independence from the British Empire and the Treasury was asked to provide some answers for the questions that would be asked. Most of the questions focused on Malaya's membership of the Sterling Area, and the Treasury, Bank and Colonial Office advised the Lord Chancellor to avoid speculative answers and only talk about details if pressed, and then only to emphasise the benefits of the Sterling Area, from information which the Bank, Treasury and Colonial Office had generated numerous times before in persuading Malaya to remain as part of the Sterling Area after independence. ${ }^{81}$

The Bank, however, suggested to Lord Kilmuir that if the topic of Malaya's dollar earnings came up, he should emphasise that Malaya's dollar earnings could not be considered in isolation, as "the fact that she chooses to convert them into Sterling and hold her reserves in that currency instead of in dollars enables her to obtain the advantages of Sterling Area membership". ${ }^{82}$ This became a particularly pointed issue with Malaya seeking its own dollar reserves, independent from the Sterling Area's general pool, following independence. ${ }^{83}$

Over a month after Malayan independence, Britain's reserve position was still extremely precarious, leading the Chancellor, Peter Thorneycroft, to make the following statement to the Cabinet:

"We have been near to the edge of economic disaster. We are still near the edge. Over the past two months we have lost $\$ 185$ millions from our gold and dollar reserves. The reserves at the end of September were down to $f 660$ millions, only two-thirds of what they were at the end of 1954, despite the $£ 200$ millions which we drew from the International Monetary Fund (I.M.F.) last year and the $£ 37$ millions which we gained by not paying last year's interest on the American loan". ${ }^{84}$

While the Chancellor cited the means of supporting the UK position as the dollars the UK had already borrowed and deflationary domestic policies, Malayan dollars at this point were as crucial as ever in propping up Britain's precarious reserve position, and discussions over Malaya's position within the Sterling Area still retained particular significance.

Following independence, the Colonial Secretary submitted to Parliament his Annual Report, detailing the events in Malaya up to $31^{\text {st }}$ August 1957. His report revealed that the 
Emergency had declined in seriousness in 1957 as it had in the four years previously. In fact, in July 1957, it was the first month since July 1948 in which the Communist insurgents did not kill anyone, there were also no reported casualties by the security forces in Malaya, and there were no major incidents relating to the Emergency. ${ }^{85}$ The prosecution of the Emergency was considered by the Colonial Office to have been extremely successful with around half of the whole country declared free of insurgent activity. Indeed, by $31^{\text {st }}$ August 1957, the number of active terrorists had dropped from a peak of 8,000 in 1951 to around 1,830, with an estimated 10,000 terrorists killed, captured of surrendered since the Emergency was declared in 1948; and security forces had suffered around 9,000 killed, wounded and missing in the same time. ${ }^{86}$

With independence, the insurgency in Malaya lost its principal justification and resistance to Commonwealth and Malayan troops dwindled swiftly, though the Emergency itself lasted formally until 1960. However, while independence heralded the formal exit of Malaya from the British Empire, the relationship between Britain and Malaya remained fundamentally the same through the institution of the Sterling Area. Indeed, as the Movement for Colonial Freedom argued at the time, "But although politically free, Malaya has yet far to go before she can truly call herself 'independent'. For even in the instrument of independence — the London Agreement the economic and military interests of Britain still bind Malaya. ${ }^{87}$

\section{Conclusion}

The paper has argued that the fundamental relationship between Britain and Malaya does not substantially change following formal independence, as the relationship is still ultimately governed by the logic and nature of the Sterling Area mechanism as a means of managing Malayan economic and monetary policy to benefit Britain. Malaya remains important to the Sterling Area throughout this period, a fact cited by officials in the Bank, Treasury and Colonial Office, due to its large dollar earning capacity and the continued inability of the Sterling Area and Britain to balance trade with the dollar area, which is revealed by state managers and also through the meagre size of Britain's (and the Sterling Area's) convertible currency reserves.

Even after independence, when the formal vestiges of empire were removed, Malaya's relationship with Britain is still managed by these same factors, and they continue to dominate the relationship. Britain identified in Malaya a prime support for the Sterling Area, which was itself a key component for the maintenance of Sterling as an international currency and for Britain's economic vitality. While this is not to say that Malaya was essential to the British 
economy, or to the stability of Sterling, it certainly played a significant role in the strategy for maintaining the Sterling Area, which still remained a vital component of Britain's international economic policy. Without Malaya, more stringent import restrictions on dollar area goods and further emergency measures, which would have required a significant change in the quality of life for citizens of Sterling Area countries, would have been necessary and they would have seriously retarded Britain's economic recovery, as well as the recovery of global trade which was vital to Britain's economy. Indeed, it is worth noting that, in 1957, Britain retained an annual trade deficit of $\$ 667 \mathrm{~m}$ with the United States and British reserves were at their lowest point since $1952{ }^{88}$ Moreover, rubber and tin prices were over double their averages in the 1940s, while production of rubber was at its highest since records began at over 630,000 tons, and export income from both was over double what it was in $1947 .{ }^{89}$

The various arguments brought up by officials in the Bank, Treasury, and Colonial Office in this period concerning Malaya's role and membership in the Sterling Area are convincing. They reveal, not only in content, but in their existence and the frequency with which they are presented, Malaya's continued importance to the Sterling Area, British economic policy and the nature of the relationship between Britain and Malaya. While Britain certainly used Malaya to its own advantage, Malaya too benefitted from this relationship. The historical development of trade within the Sterling Area had seen Malaya hold a deficit with the UK and a surplus with the US (the very basis by which she was so valuable to the UK as a dollar earner), which meant that exiting from the Sterling Area would have been too costly to reasonably consider. This was recognised by Malayan state officials both prior to and after formal independence from Britain and ensured that they would continue to support Sterling Area membership due to the advantages it brought to the Malayan economy. Hence, the imperial relationship between Britain and Malaya is characterised by constraints and opportunities. Britain could not mercilessly exploit Malaya since development was essential to its continued value and, indeed, Malaya did continue to be valuable to Britain due to its persistent trade imbalance with the United States. Nor could Malaya simply extract itself from the imperial relationship since its economy depended upon the continuity of this relationship.

This period particularly has been seen in terms of discontinuity. ${ }^{90}$ However, looking at the content of the documents in both Bank and National Archives, in terms of the relationship between Britain and Malaya we see a very strong continuity. The same reasons prevail in this period that prevailed prior, and throughout this period. Moments one would think as intuitive 
caesuras - Schenk's de facto convertibility, Hinds and Krozewski's de jure convertibility, and the numerous phases postulated by the scholars of British imperial history and decolonisation - do not obtain..$^{91}$ Indeed, the broader interests of British capital-in-general, and the viability of Sterling as an international currency, provide a much more persuasive explanation for continuity between Britain and Malaya's relationship in this period..$^{92}$

Schenk argues that it is unfair to characterise Malayan monetary independence in terms of the shift from formal to informal empire, instead focusing on the "underlying constraints" surrounding the Malayan economy at the time. ${ }^{93}$ However, the "economic dependence" Schenk refers to is still, at heart, the core of a historically developed and unequal imperial relationship between Britain and Malaya. This is not to dismiss Schenk's work. On the contrary, her analysis of the policy alternatives for both Britain and the rest of the Sterling Area clearly identifies the political economic conditions within which Britain manages the Sterling Area, and why the Sterling Area route was taken. ${ }^{94}$ However, this also avoids framing the Sterling Area as an instrument of imperial rule. White, too, while acknowledging the importance of Malaya as a dollar earner within the Sterling Area beyond the 1950s, focuses instead on the erratic and discontinuous relationship between business and government, concluding that business never meaningfully influenced government, and thus rejecting the 'gentlemanly capitalism' thesis. ${ }^{95}$ It is that importance to the Sterling Area, and the desire for British state managers to persuade Malayan state managers of that importance, that this article has sought to expand upon.

One final conclusion of this paper is the continued value of looking not only at specific relationships within the British Empire, but also considering these in terms of the broader political economy of the time. The continued value of Economic History to any study of imperial relations is well known, and has been exhorted by a recent special issue of the Journal of Imperial and Commonwealth History; however, it is also important to emphasise the Janus-like nature of politics and economics, and that one cannot be fully understood without the other. ${ }^{96}$

\footnotetext{
${ }^{1}$ Colonial constitutional changes: policy and progress 1956-1957, October 1957, Colonial Office Memoranda on Colonial Affairs 1951-1960, MSS.292/930.6/1, Trades Union Congress Archive, Modern Records Centre, University of Warwick (MRC)

${ }^{2}$ Ibid.; Galsworthy to Monson, $3^{\text {rd }}$ December 1956, CO1030/903, TNA

${ }^{3}$ For examples of 'classical' theories of imperialism, see Lenin (1934), Hilferding (1981), Bukharin (2003). For Dependency School theorists, see Amin (1977), Cohen (1973), Frank (1978). For further development on this theme, see Sutton (2013), Kettell \& Sutton (2013), Pradella (2013).

${ }^{4}$ Krozewski (1996, 15; 2001, 186); Hinds (2001, 200-201)

${ }^{5}$ Schenk (1994; 1996); Strange (1971); White (2000; 2003; 2010); Harper (2001)

${ }^{6}$ White $(2010,175)$
} 
${ }^{7}$ Harper (2001, 362-363); Amin and Caldwell (1977)

${ }^{8}$ Harper $(2001,362)$

${ }^{9}$ Strange (1971, 96-103); Schenk (1993)

${ }^{10}$ Schenk (1993:428)

${ }^{11}$ This is a well established point in the literature.

${ }^{12}$ Krozewski (2001), Hinds (2001), Schenk (1994), Strange (1971)

${ }^{13}$ Strange (1971) and Schenk (1993) focus on the development of the Malayan Central Bank; White (2000) considers the relationship British and Malayan governments have with business interests; Harper (2001) focuses on a variety of issues including communal politics in Malaya but always from a Malayan perspective.

${ }^{14}$ See, inter alia, White (1996; 1997; 2000; 2003); Stockwell (1984; 1998); Schenk (1993; 1994; 1996; 2008); Lim (1967); Krozewski (1997; 1996; 1993; 2001); Jomo (1988); Holland ((1984; 1985); Hinds (1987; 1999; 2001); Harper (2001); Darwin (1988; 2006; 2009); Curtis (2003; 2004); Cain \& Hopkins (1993); Amin \& Caldwell (1977)

${ }^{15}$ Import of Synthetic Rubber into the United Kingdom, $2^{\text {nd }}$ December 1955, CO1030/58, (TNA)

${ }^{16} \mathrm{Ibid}$.; Galsworthy to Monson, $3^{\text {rd }}$ December 1956, CO1030/903, The National Archives (TNA)

${ }^{17}$ Colonial Office to High Commissioner, Federation of Malaya, $13^{\text {th }}$ December 1955, CO $1030 / 58$, TNA

${ }^{18} \operatorname{Lim} 1967,317$

${ }^{19}$ Colonial Office to High Commissioner, Federation of Malaya, $13^{\text {th }}$ December 1955 CO $1030 / 58$, TNA ${ }^{20} \mathrm{Ibid}$.

${ }^{21} \mathrm{Ibid}$. This seemed a peculiar thing to say since the Colonial Office's stated figure of 70,000 tons accounted for around 11\% of Malaya's entire rubber crop in 1956 (calculated from Barlow 1978, Appendix 3.1). The figure then, while not representing an amount that would have a massive impact on the price of natural rubber was an enormous quantity of rubber and, therefore, of great importance to the Malayan economy.

${ }^{22}$ Malaya, $17^{\text {th }}$ January 1956, OV65/4, Bank of England Archives (BE)

${ }^{23}$ Cyprus was allowed to seek to satisfy its capital requirements in London though very specific conditions came together to permit this allowance.

${ }^{24}$ Ibid.

${ }^{25}$ Ibid.

${ }^{26}$ Indeed, a memo from the Colonial Office stresses the importance placed upon the needs of the Colonies, which resonates well with Burnham's $(2003,185)$ characterisation of the Collective Approach as moving "only as fast as the slowest and least-willing country": "We consider that Colonial claims on the UK must be put in a special category of their own, since the Colonies are, so to speak a part of us, and constitute a first and direct responsibility of HMG. Failure to carry out these responsibilities must have repercussions on the internal position of the UK itself - probably more so than in the case of many of our other external commitments." (Memorandum on Overseas Expenditure by the Chancellor, $9^{\text {th }}$ January 1956, CO1025/56, TNA)

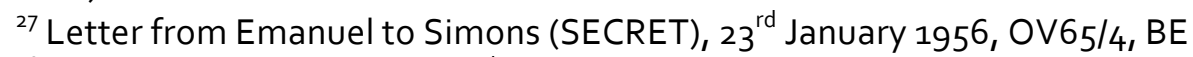

${ }^{28}$ Hong Kong Free Market, $26{ }^{\text {th }}$ January 1956, OV65/4, BE

${ }^{29}$ The Federation of Malaya - Constitutional Conference, $30^{\text {th }}$ January 1956, OV65/4, BE

${ }^{30}$ Hong Kong Free Market, $26^{\text {th }}$ January 1956 , OV65/4, BE

${ }^{31}$ The Federation of Malaya - Constitutional Conference, $30^{\text {th }}$ January 1956, OV65/4, BE

${ }^{32}$ The issue of Malayan development has also been the subject of some debate. Principally, this exists between Bauer $(1957 ; 1973)$ and Rudner $(1972 ; 1973 ; 1976)$. Where Rudner argues that British involvement in Malayan post-war development was 'hands off', Baver offers a more nuanced understanding, arguing that Britain's involvement was sporadic but ultimately unsuccessful. In more recent literature, White (1996, 213) broadly agrees with Baver, while Krozewski (2001) and Hinds (2001) support the 'disengagement' idea of Rudner.

33 ibid.; Singapore: Free US Dollar Market, $4^{\text {th }}$ February 1956, OV65/4, BE

${ }^{34}$ Letter from Morford to PL Hogg, $31^{\text {st }}$ January 1956, OV65/4, BE

${ }^{35}$ Singapore: Free US Dollar Market, $4^{\text {th }}$ February 1956, OV65/4, BE

${ }^{36}$ Ibid. 
${ }^{37}$ The Federation of Malaya - Constitutional Conference, $13^{\text {th }}$ February 1956 , OV65/4, BE

$3^{8} \mathrm{lbid}$.

${ }^{39}$ Ibid.

${ }^{40}$ Federation of Malaya, $21^{\text {st }}$ February $1956, C A B 129 / 79$, TNA

${ }^{41}$ Brittain to Lloyd, $20^{\text {th }}$ February 1956, CO1025/56, TNA

${ }^{42}$ Lloyd to Brittain, $3^{\text {rd }}$ February $1956, \mathrm{CO}_{1025} / 56$, TNA

${ }^{43} \mathrm{lbid}$.

${ }^{44}$ Bank 1970, 162

${ }^{45}$ The Federation of Malaya - Minister of Finance, $29^{\text {th }}$ February 1956, OV65/4, BE

${ }^{46}$ Ibid.

${ }^{47}$ Malaya: Industrial Development Corporation, $8^{\text {th }}$ June 1956 , OV65/5, BE

${ }^{48} \mathrm{lbid}$. See also note 7 .

${ }^{49} \mathrm{lbid}$.

${ }^{50}$ Hennings to Johnston, $18^{\text {th }}$ June $1956, \mathrm{CO}_{1030} / 903$, TNA

${ }^{51}$ Malaya, $20^{\text {th }}$ August 1958, OV65/6, BE

${ }^{52}$ High Commissioner, Malaya to Colonial Secretary, $30^{\text {th }}$ June 1956, CO1029/112, TNA

${ }_{53} \mathrm{lbid}$. The Colonial Office realized that they were stuck between two difficult positions regarding end-use information concerning Malayan rubber to China. On the one hand, the Government would be criticised for being inept, or naïve, by insisting on end-use information, and the trade would be lost since the Chinese would not agree. Alternatively, if Britain did permit the trade, there might be complaints from the Americans that the British were not enforcing controls on Chinese trade properly (Record of phone conversation between Edden and Rolleston, $5^{\text {th }}$ October 1956, CO1029/112, TNA).

${ }^{54}$ Telegram no.482: China Trade Controls: Rubber, $9^{\text {th }}$ October 1956, CO1029/112, TNA

${ }^{55}$ Sterling and the Suez Canal Situation, $1^{\text {st }}$ August $1956, \mathrm{G} 1 / 124, \mathrm{BE}$

${ }^{56}$ Ibid.

${ }^{57}$ Bank 1970, 162

$5^{8} \mathrm{lbid}$.

${ }^{59}$ Discussion with Leslie Rowan, $13^{\text {th }}$ November $1956, \mathrm{G} 1 / 124, \mathrm{BE}$

${ }^{60}$ Ibid.; Exchange Market Tactics, $3{ }^{\text {rd }}$ December 1956 C43/31, BE; Bank 1970, 162) While Treasury and Bank officials were unsure of how successful the Chancellor's statement on $4^{\text {th }}$ December 1956 would in boosting confidence of Sterling, the reserves did see a boost. The Bank decided to hold Sterling rates at their current levels but in the event of a speculative attack, they were told take no action in preventing a fall in quotations of forward Sterling. However, there was more concern about the domestic political situation and whether this would see the Conservative government collapse (Exchange Market Tactics, $3^{\text {rd }}$ December 1956, C43/31, BE)

${ }^{61}$ IBRD 1955, 48; Galsworthy to Monson, $3^{\text {rd }}$ December 1956, CO1030/903, TNA

${ }^{62}$ Galsworthy to Monson, $3^{\text {rd }}$ December 1956, CO1030/903, TNA

${ }^{6}$ Letter from Commissioner-General, SE Asia to Colonial Secretary, $6^{\text {th }}$ December 1956, CO1030/903, TNA

${ }^{64}$ Sir Robert Scott makes the argument that generous aid is, in a sense, "an insurance premium" to cover those investments since their protection depended on a stable, friendly and prosperous Malaya. He also points out that British military strength east of Suez relied on bases in Malaya. The Anglo-Malayan Defence Agreement legally permitted the UK to maintain forces in the Federation for the fulfilment of Commonwealth and international obligations, as well as to assist the Federation in defending its territory. An agreement with New Zealand and Australia also made available their forces "to continue to assist the Government of the Federation in its campaign against the Communist terrorists." (Federation of Malaya, $27^{\text {th }}$ February $1958 \mathrm{CO}_{1030 / 627}$, TNA; Letter from Commissioner-General, SE Asia to Colonial Secretary, $6^{\text {th }}$ December 1956, CO1030/903, TNA)

${ }^{65}$ Letter from Commissioner-General, SE Asia to Colonial Secretary, $6^{\text {th }}$ December $1956, \mathrm{CO}_{1030 / 903}$, TNA

${ }^{66}$ Tunku Rahman to Colonial Secretary, $7^{\text {th }}$ December 1956, CO1030/904, TNA

${ }^{67}$ Questions affecting the Federation of Malaya in relation to Sterling Area Policies, $12^{\text {th }}$ December 1956, OV65/5, BE

${ }^{68}$ Malaya and the Sterling Area, $28^{\text {th }}$ December 1956, OV65/5, BE

${ }^{69}$ The Malayans argued this was legitimate as the Emergency was not a 'local war' but a major part of the 
worldwide battle against Communism (Note for Prime Minister, $8^{\text {th }}$ January 1957, CO1030/903, TNA)

${ }^{70}$ Note for Prime Minister, $8^{\text {th }}$ January 1957, CO1030/903, TNA

${ }^{71} \mathrm{lbid}$.

72 Telegram no.59, $10^{\text {th }}$ January 1957, CO1030/903, TNA

${ }^{73}$ It was to be decided at the time whether the fund would take the form of a grant, a low-interest loan, or a split between the two (Telegram no.59, $10^{\text {th }}$ January 1957, CO1030/903, TNA)

74 ibid.; Federation of Malaya, $27^{\text {th }}$ February 1958 , CO1030/627, TNA)

75 Telegram no.59, $10^{\text {th }}$ January $1957, \mathrm{CO}_{1030 / 903}$, TNA

${ }^{76} \mathrm{Abdul}$ Rahman went so far as to say that, considering the UK's financial position at the time, the terms were extremely generous (Telegram no.59, $10^{\text {th }}$ January 1957, $\mathrm{CO}_{1030} / 903$, TNA)

77 IBRD 1955, 212; Federation of Malaya Post Office Savings Bank, $30^{\text {th }}$ May 1957, OV65/5, BE

${ }^{78}$ IBRD 1955, 212; Federation of Malaya Post Office Savings Bank, $30^{\text {th }}$ May 1957, OV65/5, BE

${ }^{79}$ Exchange Policy, $11^{\text {th }}$ January 1957, C43/31, BE

${ }^{80}$ Federation of Malaya, $27^{\text {th }}$ February $1958, \mathrm{CO}_{1030} / 627$, TNA

${ }^{81}$ Hennings to Charles, $10^{\text {th }}$ September 1957 , OV65/5, BE

${ }^{82}$ Ibid.

${ }^{83}$ Malayan Desire to Hold Dollars, $11^{\text {th }}$ June 1958 , OV65/5, BE; Telegram no.756, $18^{\text {th }}$ October 1958 , T236/5151 TNA

${ }^{84}$ The Economic Situation, $14^{\text {th }}$ October 1957, CAB129/89, TNA

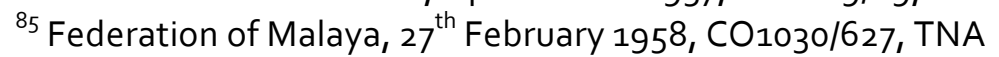

${ }^{86}$ Ibid.

${ }^{87}$ PROD: Colonial Freedom News, Movement for Colonial Freedom, September 1957, MSS.29/930/3, Trades Union Congress Archive, MRC

${ }^{88}$ Mitchell \& Jones (1971,140); Bank of England Statistical Abstract (1970)

${ }^{89} \operatorname{Lim}(1967)$

${ }^{90}$ See, inter alia, Darwin (1988; 2006), Hinds (2001), Holland (1984; 1985), Krozewski (1997; 2001), Schenk (1996).

${ }^{91}$ Schenk (1994, 128; 1996, 870); Krozewski (1997, 850); Hinds (2001, 201).

${ }^{92}$ A similar conclusion is reached by Attard (2013) and Attard \& Dilley $(2013,4)$, who emphasize the "ongoing interests" of British capital as the basis for continuity in Queensland colony in the 186os. Their work also underscores the continued value of understanding the nuanced character of historical political economy in conceiving imperial relations (ibid., 2). This is a point also made by Burnham (2006) in slightly broader theoretical terms of understanding the British state in terms of the nature of social relations themselves.

${ }^{93}$ Schenk (1993:428)

${ }^{94}$ Schenk (1992:282-284)

${ }^{95}$ White (1994:270)

${ }^{96}$ See Journal of Imperial and Commonwealth History 41:4 (2013). 


\section{References}

Amin, Mohamed and Malcolm Caldwell (eds.). Malaya: The Making of a Neo-Colony. Nottingham: Spokesman, 1977

Amin, Samir. Imperialism and Unequal Development. New York: Monthly Review Press, 1977

Attard, Bernard. Bridgeheads, 'Colonial Places' and the Queensland Financial Crisis of 1866. Journal of Imperial and Commonwealth History 41:1 (2013)

Attard, Bernard \& Andrew Dilley. Finance, Empire and the British World. Journal of Imperial and Commonwealth History 41:1 (2013)

Bauer, P.T. Post War Malayan Rubber Policy: A Comment. Journal of South East Asian Studies 4 (1973)

Bauer, P.T. Malayan Rubber Policy. Political Science Quarterly 72:1 (1957)

Bank of England Statistical Abstract No.1. London: HMSO, 1970

Bukharin, Nikolai; Imperialism and World Economy; Bookmarks, London (2003)

Burnham, Peter. Marxism, the State, and British Politics. British Politics 1 (2006)

Burnham, Peter. Remaking the Postwar World Economy: Robot and British Policy in the 19505. London: Palgrave Macmillan, 2003

Cain, P.J. and A.G. Hopkins. British Imperialism: Crisis and Deconstruction 1914-1990. New York: Longman, 1993

Cohen, Benjamin J. The Question of Imperialism. New York: Basic Books, 1973

Curtis, Mark. Britain's Real Foreign Policy and the Failure of British Academia. International Relations 18:3 (2004)

Curtis, Mark. Web of Deceit: Britain's Real Role in the World. London: Vintage, 2003

Darwin, John. The Empire Project. Cambridge: Cambridge University Press, 2009

Darwin, John. The End of the British Empire: The Historical Debate. London: Wiley Blackwell, 2006

Darwin, John. Britain and Decolonisation: The Retreat from Empire in the Post-War World. London: 
Macmillan, 1988

Dumett, Raymond E. (ed.). Gentlemanly Capitalism and British Imperialism: The New Debate on Empire. London: Longman, 1999

Frank, Andre Gunder. Dependent Accumulation and Underdevelopment. London: Macmillan, 1978

Harper, T.N. The End of Empire and the Making of Malaya; Cambridge University Press, Cambridge (2001)

Hilferding, Rudolf. Finance Capital: A Study of the Latest Phase in Capitalist Development. London: Routledge, 1981

Hinds, Allister. Britain's Sterling Colonial Policy and Decolonisation, 1939-1958. London: Greenwood Press, 2001

Hinds, Allister. Sterling and Decolonisation in the British Empire, 1945-1958. Social and Economic Studies 48:4 (1999)

Hinds, Allister. Sterling and Imperial Policy, 1945-1951. The Journal of Imperial and Commonwealth History 15:2 (1987)

Hobsbawm, Eric. Industry and Empire: From 1750 to the Present Day. London: Penguin, 1999

Holland, R.F. European Decolonisation 1918 - 1981: An Introductory Survey. London: Macmillan, 1985

Holland, R.F. 'The Imperial Factor in British Strategies from Atlee to MacMillan, 1945-1963' in Perspectives on Imperialism and Decolonisation, edited by R.F. Holland and G. Rizvi. London: Frank Cass, 1984

International Bank for Reconstruction and Development. The Economic Development of Malaya. Baltimore: The Johns Hopkins Press, 1955

Jen, Li Dun. British Malaya: An Economic Analysis. New York: The American Press, 1955

Jomo, K.S. A Question of Class: Capital, the State and Uneven Development in Malaya. New York: Monthly Review Press, 1988

Kettell, Steven and Sutton, Alex. New Imperialism: Towards a Holistic Approach International Studies Review 15:2 (2013) 
Krozewski, Gerold. Money and the End of Empire: British International Economic Policy and the Colonies, 1947-58. Cambridge: Cambridge University Press, 2001

Krozewski, Gerold. Sterling, the 'Minor' Territories, and the End of Formal Empire, 1939-1958. Economic History Review 46:2 (1993)

Krozewski, Gerold. Finance and Empire: The Dilemma Facing Great Britain in the 1950 . International History Review 18:1 (1996)

Krozewski, Gerold. Finance and Empire: A Note in Reply to Catherine R. Schenk. International History Review 19:4 (1997)

Lenin, V.I. Imperialism: The Highest Stage of Capitalism. New York: International Publishers, 1934

Lim, Chong-Yah. Economic Development of Modern Malaya. Kuala Lumpur: Oxford University Press, 1967

Mitchell, B.R. and H.G. Jones. Second Abstract of British Historical Statistics. Cambridge: Cambridge University Press, 1971

Porter, A.N. and A.J. Stockwell. British Imperial Policy and Decolonisation. London: Macmillan, 1987

Pradella, Lucia. Imperialism and Capitalist Development in Marx's Capital. Historical Materialism 21:2 (2013)

Rudner, Martin. Malayan Rubber Policy: Development and Anti-Development during the 19505. Journal of Southeast Asian Studies 7:2 (1976)

Rudner, Martin. Financial Policies in Post-War Malaya: The Fiscal and Monetary Measures of Liberation and Reconstruction. Journal of Imperial and Commonwealth History 3 (1975)

Rudner, Martin. The Draft Development Plan of the Federation of Malaya. Journal of Southeast Asian Studies 3:1 (1972)

Rudner, Martin. Rubber Strategy for Post-War Malaya: 1945-48. Journal of Southeast Asian Studies 1:1 (1970)

Schenk, Catherine R. Malaysia and the End of the Bretton Woods System, 1965-72: Disentangling from Sterling. Journal of Imperial and Commonwealth History 36:2 (2008) 
Schenk, Catherine R. Finance and Empire: Confusions and Complexities: A Note. International History Review 18:4 (1996)

Schenk, Catherine R. Britain and the Sterling Area: From Devaluation to Convertibility in the 1950 . London: Routledge, 1994

Schenk, Catherine R. The Origins of a Central Bank in Malaya and the Transition to Independence, 1954-59. Journal of Imperial and Commonwealth History 21:2 (1993)

Schenk, Catherine R. The Sterling Area and British policy Alternatives in the 1950s. Contemporary Record 6:2 (1992)

Stockwell, A.J. Malaysia: The Making of a Neo-Colony?. Journal of Imperial and Commonwealth History 26:2 (1998)

Stockwell, A.J. British Imperial Policy and Decolonisation in Malaya, 1942-52. Journal of Imperial and Commonwealth History 13:1 (1984)

Strange, Susan. Sterling and British Policy: A Political Study of an International Currency in Decline. London: Oxford University Press, 1971

Sutton, Alex. Towards an Open Marxist Theory of Imperialism. Capital \& Class 37:2 (2013)

Tomlinson, B.R. The Contraction of England: National Decline and the Loss of Empire. Journal of Imperial and Commonwealth History 11:1 (1982)

Tomlinson, Jim. The Decline of the Empire and the Economic 'Decline' of Britain. Twentieth Century History Review 14:3 (2003)

White, Nicholas. 'Malaya and the Sterling Area Reconsidered: Continuity and Change in the 1950s.' in The International Order of Asia in the 1930 s and the 1950s, edited by Akita Shigeru and Nicholas White Aldershot: Ashgate, 2010

White, Nicholas. The Survival, Revival and Decline of British Economic Influence in Malaysia, 195770. Twentieth Century British History 14:3 (2003)

White, Nicholas. British Business Groups and the Early Years of Malaysian Independence, 1957-65, Asia Pacific Business Review 7 (2000)

White, Nicholas. The Frustrations of Development: British Business and the Late Colonial State in 
Malaya, 1945-57. Journal of Southeast Asian Studies 28:1 (1997)

White, Nicholas. Business, Government, and the End of Empire: Malaya, 1942 - 1957; Oxford: Oxford University Press, 1996

White, Nicholas. Government and Business Divided: Malaya 1945 - 1957. Journal of Imperial and Commonwealth History 22:2 (1994) 